\title{
Communication
}

[Comunicação]

\section{Mycobacterium avium subspecies paratuberculosis and bovine leukemia virus seroprevalence and associated risk factors in dairy herds in Minas Gerais state, Brazil}

[Soroprevalência do Mycobacterium avium subespécie paratuberculosis e vírus da leucemia bovina e fatores de risco associados em rebanhos leiteiros de Minas Gerais, Brasil]

\author{
M.A. Souza $a^{1,2}$, B.A. Silva ${ }^{3}$, C.F. Nascimento ${ }^{4}$, I.J. Reis ${ }^{5}$, M.P. Reis ${ }^{5}$, \\ H. Júnior Filho ${ }^{5}$, A.L. Azevedo $o^{5}$, J.R. Castro ${ }^{2}$, A.M.C. Lima ${ }^{6}$
}

${ }^{1}$ Aluna de pós-graduação - Faculdade de Medicina Veterinária - Universidade Federal de Uberlândia, Uberlândia - MG

${ }^{2}$ Faculdade de Medicina Veterinária - Centro Universitário de Patos de Minas - Patos de Minas, MG ${ }^{3}$ Aluno de pós-graduação - Escola de Veterinária - Universidade Federal de Minas Gerais - Belo Horizonte, MG

${ }^{4}$ Aluna de pós-graduação - Universidade Estadual Paulista Júlio Mesquita Filho, Jaboticabal, SP

${ }^{5}$ Aluno de graduação - Centro Universitário de Patos de Minas, Patos de Minas, MG

${ }^{6}$ Faculdade de Medicina Veterinária - Universidade Federal de Uberlândia - Uberlândia, MG

In 2016, Brazil produced 33.62 billion liters of milk. The state of Minas Gerais, the country's largest dairy producer, accounted for $26.7 \%$ of national production (Ranking..., 2017). This significant commercial presence in the agricultural market points to the need for more effective sanitary measures and investigations of diseases in dairy herds to ensure product competitiveness and quality.

Paratuberculosis (PTB) or Johne's disease is an infection characterized by chronic granulomatous enteritis caused by Mycobacterium avium subsp. paratuberculosis (MAP), which affects cattle, sheep, goats and wild ruminants (Fecteau, 2017). Enzootic bovine leukosis EBL is caused by an RNA virus of the Retroviridae family, the bovine leukemia virus (BLV). Considering the economic impact of PTB and EBL and the importance of an epidemiological analysis to support prophylactic measures, our objective here was to conduct a seroepidemiological study of PTB and EBL in cattle herds in the largest dairy basin in the state of Minas Gerais, Brazil. This research was approved by the Ethics Committee on Animal Use of the University Center of Patos de Minas (UNIPAM), under Protocol no. 54/17. The study was carried out in the municipality of Lagoa
Formosa, located in the region of Alto Paranaíba, state of Minas Gerais, Brazil. To determine the sample size, the prevalence estimation method was used on a simple random sample. Estimated prevalence was $75.8 \%$ for paratuberculosis (Fernández-Silva et al., 2014) and $80.89 \%$ for leukosis (Ambrósio, 2015). Thus, for the sample size an expected prevalence of $81 \%$ was adopted with a $95 \%$ confidence level and a statistical error of $5 \%$, indicating a minimum total sample size of 236 samples.

Forty farms were selected randomly in the north, south, east and west regions according to the zoning map provided by the municipal government. The samples were collected from a total of 10 farms per region. The herds consisted of animals of various breeds and ages, in different stages of lactation, raised in intensive or semiintensive systems and subjected to mechanical and/or manual milking. Blood samples were drawn exclusively from lactating cows. A total of 236 blood samples were collected by coccygeal venipuncture, using sterile $10 \mathrm{~mL}$ syringes and $25 \mathrm{~mm} \times 0.7 \mathrm{~mm}$ needles. The blood was stored in tubes without anticoagulant and kept on ice in styrofoam boxes. The samples were sent to the Laboratory of Infectious Diseases of UNIPAM,

Recebido em 29 de fevereiro de 2020

Aceito em 27 de outubro de 2020

E-mail:marianaa@unipam.edu.br 
where they were centrifuged at $3000 \mathrm{~g}$ for $5 \mathrm{~min}$ to extract the serum. They were then frozen in Eppendorf microtubes at $-20^{\circ} \mathrm{C}$ until the tests were performed.

Serological diagnosis of PTB was performed using a commercial kit for indirect ELISA antibody testing for Mycobacterium avium subsp. paratuberculosis (IDEXX Laboratories Inc. Westbrook, ME, USA). The presence of antibodies against BLV was evaluated using a commercial agar-gel immunodiffusion (AGID) test (Tecpar Laboratories, Paraná, Brazil), following the manufacturer's instructions. Reading and interpretation of the test results was carried out under strong light after 24, 48 and $72 \mathrm{~h}$ of incubation in a dark environment to ascertain the appearance of precipitation lines.

A structured questionnaire with closed-ended questions was created and applied to farm administrators to obtain information on the major risk factors associated with the animal-level and herd-level target prevalence. The variables investigated for MAP were age; presence of chronic diarrhea; raw milk consumption; veterinary service; newborn calf management; cleansing the teats before allowing the calf to suckle; contact by calves with adult animal feces; presence of dung heaps; and trade of animals. The variables investigated for BLV were age; use of disposable needles; reuse of veterinary obstetric gloves; veterinary service; presence of bloodsucking flies; trade of animals; application of oxytocin during milking; blood transfusion; and type of reproductive management (natural mating and/or artificial insemination).

To calculate frequency, the number of cows with antibodies against MAP and BLV in relation to the number of sampled animals was established, using descriptive statistical analysis, by means of absolute and relative frequency. The statistical analysis of association between the investigated variables and the serological status was evaluated considering the Odds Ratio nonparametric test with a $95 \%$ confidence interval as the dependent variable. A p-value of $<0.05$ was considered statistically significant. The analyses were performed using GraphPad version 5.0 software (San Diego, California, USA).

In eight of the 40 herds evaluated $(20 \%, 95 \% \mathrm{CI}$ : 7.60-32.39\%), at least one animal had antibodies against MAP. Among the 236 cows examined, 14 (6\%, 95\% CI: $2.98-9.02 \%)$ were reactive. The animals presented no clinical symptoms suggestive of infection by MAP. As for the risk factors investigated in the epidemiological survey, a significant association was identified between MAP and newborn calf management $(\mathrm{P}<0.0001)$ and contact by calves with adult animal feces $(\mathrm{p}=0.0258$; Table 1$)$.

Table 1. Distribution of cows from dairy herds with antibodies against MAP, according to the evaluated risk factors, in the municipality of Lagoa Formosa, MG, Brazil, 2017.

\begin{tabular}{|c|c|c|c|c|c|c|}
\hline \multirow[t]{2}{*}{ Variable } & \multicolumn{3}{|c|}{ Cows } & \multirow[t]{2}{*}{$O R^{*}$} & \multirow[t]{2}{*}{ CI $95 \%$} & \multirow[t]{2}{*}{$\mathrm{P}$} \\
\hline & Total & Reagents & $\begin{array}{c}\text { Frequency } \\
(\%)\end{array}$ & & & \\
\hline \multicolumn{7}{|l|}{ Animal trade } \\
\hline Yes & 104 & 6 & 5.76 & 0.9490 & $0.3186-2,827$ & 1,0000 \\
\hline No & 132 & 8 & 6.06 & & & \\
\hline \multicolumn{7}{|c|}{ Newborn calf management } \\
\hline Along adults & 67 & 13 & 19.40 & 41.45 & $5,295-324.5$ & $<0.0001$ \\
\hline Separated adults & 169 & 1 & 0.59 & & & \\
\hline \multicolumn{7}{|l|}{ Veterinary care } \\
\hline Yes & 140 & 9 & 6.42 & 1,250 & $0.4056-3.854$ & 0.7849 \\
\hline No & 96 & 5 & 5.20 & & & \\
\hline \multicolumn{7}{|c|}{ Raw milk consumption } \\
\hline Yes & 205 & 11 & 5.36 & 0,486 & $0.1272-1.859$ & 0.3899 \\
\hline No & 31 & 3 & 9.67 & & & \\
\hline \multicolumn{7}{|c|}{ Contact of calves with adult feces } \\
\hline Yes & 133 & 12 & 9.02 & 5,008 & $1.095-22.91$ & 0.0258 \\
\hline No & 103 & 2 & 1.94 & & & \\
\hline
\end{tabular}


The herd-level prevalence was $85 \%(38 / 40,95 \%$ CI: $82.16-87.84 \%)$ and the animal-level prevalence was $50.42 \%(119 / 236,95 \%$ CI: $49.51-$ $51.32 \%)$. In addition, all the animals examined on three farms were reactive to BLV. With regard to the risk factors analyzed for BLV, the variables 'blood transfusion' ( $\mathrm{p}=0.0027)$, 'veterinary care' $(\mathrm{p}=0.0005)$ and 'reproductive management' $(\mathrm{p}=0.0319)$ showed a significant association with the presence of anti-BLV antibodies (Table 2).

Table 2. Distribution of cows from dairy herds with antibodies against BLV, according to the evaluated risk factors, in the municipality of Lagoa Formosa, MG, Brazil, 2017.

\begin{tabular}{|c|c|c|c|c|c|c|}
\hline \multirow{2}{*}{ Variable } & \multicolumn{3}{|c|}{ Cows } & \multirow{2}{*}{$O R^{*}$} & \multirow{2}{*}{ CI $95 \%$} & \multirow[t]{2}{*}{$\mathrm{P}$} \\
\hline & Total & Reagents & $\begin{array}{c}\text { Frequency } \\
(\%)\end{array}$ & & & \\
\hline \multicolumn{7}{|l|}{ Age } \\
\hline $20-48$ months & 62 & 27 & 43.54 & 0.6876 & $0.38-1.23$ & 0.2377 \\
\hline$>4$ years & 174 & 92 & 52.87 & & & \\
\hline \multicolumn{7}{|l|}{ Disposable needles } \\
\hline Yes & 10 & 4 & 40.00 & 0.64 & $0.17-2.34$ & 0.5373 \\
\hline No & 226 & 115 & 50.88 & & & \\
\hline \multicolumn{7}{|l|}{ Reuse gloves } \\
\hline Yes & 161 & 87 & 54.03 & 1.58 & $0.90-2.74$ & 0.1243 \\
\hline No & 75 & 32 & 42.66 & & & \\
\hline \multicolumn{7}{|l|}{ Use oxytocin } \\
\hline Yes & 5 & 5 & 100 & 11.29 & $0.61-206.6$ & 0.0599 \\
\hline No & 231 & 114 & 49.35 & & & \\
\hline \multicolumn{7}{|l|}{ Blood transfusion } \\
\hline Yes & 83 & 53 & 63.85 & 2.32 & $1.34-4.038$ & 0.0027 \\
\hline No & 153 & 66 & 43.13 & & & \\
\hline \multicolumn{7}{|l|}{ Animal trade } \\
\hline Yes & 104 & 57 & 54.80 & 1.36 & $0.81-2.294$ & 0.2410 \\
\hline No & 132 & 62 & 46.96 & & & \\
\hline \multicolumn{7}{|l|}{ Veterinary care } \\
\hline Yes & 140 & 84 & 60.00 & 2.61 & $1.53-4.468$ & 0.0005 \\
\hline No & 96 & 35 & 36.84 & & & \\
\hline \multicolumn{7}{|c|}{ Reproductive management } \\
\hline Natural mating & 51 & 30 & 58.82 & $2.27 \quad 1$ & $1.117-4.639 * *$ & 0.0319 \\
\hline AI & 102 & 57 & 55.88 & & & \\
\hline Natural mating $+\mathrm{AI}$ & 83 & 32 & 38.55 & & & \\
\hline
\end{tabular}

*Odds Ratio; **OR calculated for the greatest difference between proportions; AI: artificial insemination; $\mathrm{P}<0.05$ indicates a significant difference.

Asymptomatic cattle testing positive for MAP by ELISA are considered important sources of infection because they may discharge the bacillus intermittently into the environment, thereby contaminating water and food (Fecteau, 2017). The prevalence of antibodies against MAP detected in $20 \%$ of the herds in this study may be even higher given that the disease has a relatively long latency period of 2-10 years and levels of antibodies against MAP are detected only at the end of this period. Studies into the occurrence of MAP are rare in the state of Minas Gerais, and there is no available survey containing official data about the epidemiological situation in Brazil. Surveys conducted in other Brazilian regions have shown higher MAP prevalence rates among herds than the one reported here (Yamasaki et al., 2010; Vilar et al., 2015).

In the Odds Ratio analysis, it was found that cows older than 4 years had a greater chance of becoming infected with MAP than cows between 20 and 48 months of age. The larger number of positive adult animals found in this study may also be attributed to the diagnostic method used here, since MAP antibody levels are identified only at the end of the incubation period of the disease, which may last from 2 to 10 years (Vilar et al., 2015; Fecteau, 2017). 
The variable 'newborn calf management' was significant $(\mathrm{P}<0.0001)$. In the herds where newborn calves were in frequent contact with adult cattle, an OR of 41.45 was identified. Preventing contact between young animals and adults may help to control the disease, since MAP transmission occurs mainly through the ingestion of pasture contaminated with adult feces or during the ingestion of colostrum or milk from fecescontaminated teats (Sá et al., 2013; Vilar et al., 2015). Serological surveys conducted in different regions of Brazil have shown mixed results with respect to the occurrence of leukosis, with an average rate of $27.60 \%$ of reactive animals (Starling et al., 2013; Pinheiro-Júnior et al., 2013; Ambrósio, 2015). The variable 'blood transfusion' was identified as a risk factor for $\operatorname{BLV}(p=0.0027)$, and an OR of 2.32 was identified at the farms where this procedure was employed. BLV transmission is closely tied to management practices, especially the more technified ones.

Reproductive management was also identified as a risk factor for BLV. In the herds where the animals mated naturally, a 2.27-fold higher OR was found than in herds in which reproduction was achieved through a combination of artificial insemination and natural mating. Flores (2007) states that transmission may occur through natural mating, which is a form of transmission of the virus from an infected bull to females and is due to the possible presence of lymphocytes in the reproductive tract and not necessarily to the presence of BLV in semen.
As for the variable 'veterinary service', the animals on farms where such care was available presented a 2.32-fold higher risk of having the infection $(p=0.0005)$. It is known that the main mechanism of BLV transmission is via the horizontal route, by iatrogenic transmission through procedures that enable contaminated blood to be transferred between animals (Flores, 2007). Consistent with this study, Pinheiro-Júnior et al. (2013) also identified a significant association $(\mathrm{P}<0.000)$ between the variable 'veterinary care' and the occurrence of leukosis in bovine herds in the state of Alagoas.

Given the detection of $20 \%$ of herd-level seroprevalence of antibodies against MAP identified for the first time in the region under study and the $85 \%$ herd-level seroprevalence of antibodies against BLV, the importance of implementing specific sanitary hygiene measures that include elements of surveillance based on the risks identified in this study cannot be overstated. Moreover, advice for farm administrators about the economic losses these diseases can cause should serve as an incentive to promote a change in attitude to improve the implementation of effective control measures in herds. This work received financial support from CAPES (Coordination of Improvement of Higher-Level Personnel), CNPq - no. 64/2008 (National Council for Scientific and Technological Development) and PIBIC (Institutional Program of Scientific Initiation Scholarships) of the University Center of Patos de Minas, Minas Gerais, Brazil.

Keywords: paratuberculosis, bovine leukemia, IDGA, ELISA

\section{RESUMO}

Mycobacterium avium subesp. paratuberculosis (MAP) e o vírus da leucemia bovina (BLV) são agentes que causam grandes perdas econômicas nos rebanhos. O objetivo deste estudo foi avaliar a situação epidemiológica da paratuberculose bovina (PTB) e leucose enzoótica bovina (EBL) em rebanhos leiteiros de Lagoa Formosa, Minas Gerais, Brasil. Foram coletadas 236 amostras de sangue de vacas, as quais foram submetidas aos testes ELISA e imunodifusão em gel de ágar para detecção de anticorpos contra MAP e BLV. A soroprevalência de anticorpos contra MAP e BVL foi de $20 \%$ para os rebanhos e $6 \%$ para os animais e de $85 \%$ para os rebanhos e 50,42\% para os animais, respectivamente. A presença dessas enfermidades deve servir como um alerta para os produtores e veterinários, para que concentrem maior atenção na implementação de medidas higiênico-sanitárias, incorporando elementos de vigilância com base nos riscos identificados no estudo.

Palavras-chave: paratuberculose, leucemia bovina, IDGA, ELISA 


\section{REFERENCES}

AMBRÓSIO, N.A. Intercorrência da leucose enzoótica bovina e mastite em vacas leiteiras naturalmente infectadas. 93f. 2015. Dissertação (Mestrado em Sanidade Animal) - Universidade Federal de Lavras, Lavras, MG.

FECTEAU, M.E. Paratuberculosis in catlle. Vet. Clin. North Am. Food Anim. Pract., v.34, p.209222,2017

FERNÁNDEZ-SILVA, J.A.; CORREAVALENCIA, N.M.; RAMÍREZ, N.F. Systematic review of the prevalence of paratuberculosis in cattle, sheep, and goats in Latin America and the Caribbean. Trop. Anim. Health Prod., v.46, p.1321-1340, 2014.

FLORES, E.F. Virologia veterinária. Santa Maria: UFSM, 2007. 888.

PINHEIRO-JUNIOR, J.W.; SOUZA, M.E.; PORTO, W.J.N. et al. Epidemiologia da infecção pelo vírus da leucose enzoótica bovina (LEB). Ciec. Anim. Bras. v.14, 258-264, 2013.

RANKING quantidade de leite produzida no Brasil em 2016. Rio de Janeiro: IBGE, 2017. Disponível em: https://cidades.ibge.gov.br/ brasil/pa/brasilNovo/pesquisa/18/0?tipo=ranking \&indicador $=16559 \&$ localidade $1=0 \&$ localidade 2 $=313750$. Acessado em: 17 jan. 2020 .
SÁ, L.M.; OLIVEIRA, J.M.B.; SÁNTOS, G.R. et al. Avaliação sorológica e de fatores de risco para a infecção por Mycobacterium avium sbsp. paratuberculosis em rebanhos leiteiros da microrregião de Garanhuns, Pernambuco. Pesqui. Vet. Bras., v.33, p.310-313, 2013.

STARLING, R.Z.C.; BEZERRE, A.O.; SALARDANE, I. et al. Soroepidemiologia da leucose enzoótica bovina em propriedades leiteiras do município de Alegre, estado do Espírito Santo, Brasil. J. Bras. Ciên. Anim., v.6, p.427-441, 2013.

VILAR, A.L.; SANTOS, C.S.; PIMENTA, C.L. et al. Herd-level prevalence and associated risk factors for Mycobacterium avium subsp. paratuberculosis in cattle in the State of Paraíba, Northeastern Brazil. Prev. Vet. Med., v.121, p.49$55,2015$.

YAMASAKI, E.M.; TOKARNIA, C.H.; GALVÃO, A. et al. Aspectos clínicospatológicos e controle da paratuberculose em rebanho bovino leiteiro. Pesqui. Vet. Bras. V.30, p.921-932, 2010. 